\title{
Numerical analysis of hybrid nanofluids as coolants for automotive applications
}

\author{
Gabriela Huminic*, Angel Huminic \\ Transilvania University of Brasov, Mechanical Enginering Department, 29 Bulevardul Eroilor \\ Street, Brasov 500036, Romania \\ Email: gabi.p@unitbv.ro
}

\begin{abstract}
The study the laminar convective heat transfer of hybrid nanofluids in a 3D flattened tube under constant heat flux condition was carried out. The effects of Reynolds number and concentration of hybrid nanoparticles on heat transfer characteristics of MWCNT- $\mathrm{Fe}_{3} \mathrm{O}_{4} /$ water hybrid nanofluids were numerically investigated. The simulations were performed for the Reynolds number in the range 50-1000 and for two volume concentrations of hybrid nanoparticles, $0.1 \%$ and $0.3 \%$ respectively. Results showed that the heat transfer coefficient increases with increasing volume concentration of hybrid nanoparticles and increasing Reynolds number. At low Reynolds numbers, the application of MWCNT- $\mathrm{Fe}_{3} \mathrm{O}_{4} /$ water hybrid nanofluids in flattened tube can enhance heat transfer up to $31 \%$ compared with water (base fluid). Numerically results were validated by comparison of simulations with results available in literature.
\end{abstract}

Keywords: Hybrid Nanofluids, Flat Tube, Heat Transfer.

\section{INTRODUCTION}

In past decade, extensive research was focused on applications of nanofluids in the automotive industry, especially to automotive radiator. The researches carried out so far suggest that the nanofluids could be an alternative to conventional coolants (water, ethylene glycol, water and ethylene glycol mixture) used in various thermal applications [1-3], as well in automotive radiators $[4,5]$.

Vajjha et al. [6] carried out a numerically study concerning to heat transfer characteristics of the $\mathrm{Al}_{2} \mathrm{O}_{3}$ and $\mathrm{CuO}$ nanoparticle into water-ethylene glycol mixture (40:60). The two nanofluids flow through a flattened tube under laminar flow. The heat transfer coefficient $\left(\mathrm{h}=50 \mathrm{~W} / \mathrm{m}^{2} \mathrm{~K}\right)$ and the temperature $(\mathrm{T}=303 \mathrm{~K})$ on walls of tube were imposed. The study was performed in following conditions: the Reynolds number, $\mathrm{Re}=100-2000$, the inlet temperature, $\mathrm{T}_{\text {in }}=90{ }^{\circ} \mathrm{C}$, the volume concentration of nanoparticles, $\phi=0-10 \%$ for the $\mathrm{Al}_{2} \mathrm{O}_{3}$ and $\phi=0-6 \%$ for the $\mathrm{CuO}$ nanoparticles. Their results indicated that thermal performances of the flattened tube were improved due to using nanofluids. There was an increase in heat transfer coefficient with increasing of Reynolds number and also with increasing of volume concentration of nanoparticles.

Huminic and Huminic [7] numerically investigated the effect of volume concentration of nanoparticles, of Brownian motion and of Reynolds number on thermal performances of the flattened tube using $\mathrm{CuO} /$ ethylene glycol nanofluids under laminar flow. The heat transfer coefficient $\left(\mathrm{h}=50 \mathrm{~W} / \mathrm{m}^{2} \mathrm{~K}\right)$ and the temperature $(\mathrm{T}=303 \mathrm{~K})$ on walls of tube were imposed. The boundary conditions imposed in this study was following: the Reynolds number, $\mathrm{Re}=10-125$, the inlet temperature, $\mathrm{T}_{\text {in }}=50$ ${ }^{\circ} \mathrm{C}$, the volume concentration of nanoparticles, $\phi=0-4 \%$ for the $\mathrm{CuO}$ nanoparticles. The numerical results were compared with results obtained in the case circular and elliptic tubes. The authors founded that the thermal performances of flattened tubes were significantly enhanced compared to that of the elliptic and circular tubes using $\mathrm{CuO} /$ ethylene glycol nanofluids as coolant.

Delavari et al. [8] numerically investigated heat transfer and flow characteristics of ethylene glycol and water based on $\mathrm{Al}_{2} \mathrm{O}_{3}$ nanoparticles flowing through a flattened tube under laminar and turbulent flow. Single and two-phase approaches were employed. The study was performed in following conditions: the Reynolds number, $\mathrm{Re}=1220-2440$ (laminar flow) and $\mathrm{Re}=9350-23000$ (turbulent flow), the inlet temperature, $\mathrm{T}_{\text {in }}=35-60{ }^{\circ} \mathrm{C}$, and the volume concentration of nanoparticles, $\phi=0-1 \%$. They observed that the numerical results using two-phase approach were closer to the experimental data than the results obtained using single-phase method.

Also, the heat transfer and flow characteristic of the water based $\mathrm{Al}_{2} \mathrm{O}_{3}$ and $\mathrm{CuO}$ nanoparticle flowing through a flattened tube under laminar flow were numerically investigated by $\mathrm{M}$. Elsebay et al. [9]. The study was performed in following conditions: the Reynolds number, $\mathrm{Re}=250-1750$, the inlet temperature, $\mathrm{T}_{\mathrm{in}}=80^{\circ} \mathrm{C}$, the temperature, $\mathrm{T}_{\mathrm{w}}=303 \mathrm{~K}$, the heat 
transfer coefficient, $\mathrm{h}_{\mathrm{w}}=50 \mathrm{~W} / \mathrm{m}^{2} \mathrm{~K}$ and the volume concentration of nanoparticles, $\phi=0-7 \%$. They observed that although the heat transfer coefficients increase with 45 and $38 \%$ for $\mathrm{Al}_{2} \mathrm{O}_{3} /$ water and $\mathrm{CuO} /$ water nanofluids, the increase of heat transfer coefficient was correlated with a significantly increase in the friction factor and in pressure drop of 271 and $267 \%$ for $\mathrm{Al}_{2} \mathrm{O}_{3} /$ water and 266 and $226 \%$ for $\mathrm{CuO} /$ water nanofluids.

It is known that nanofluids have a high thermal conductivity but also a high viscosity, which leads to limited use of nanofluids in the automotive industry. In last year's, research was focused on the development of new working fluids which combining of two or three solid materials into conventional fluids. These new fluids are called hybrid nanofluids. Thus, the main goal of this work is the study of influence of concentration of hybrid nanoparticles and Reynolds number on flattened tube.

\section{SOLUTION METHODOLOGY}

\subsection{Physical model}

In this study, the simulations were performed for a flattened tube of an automobile radiator (Fig. 1). The geometrical dimensions of the flattened tube were: the height, $\mathrm{H}=2.56 \mathrm{~mm}$, the width, $\mathrm{W}=16.1544 \mathrm{~mm}$, and the length, $\mathrm{L}=500 \mathrm{~mm}$.

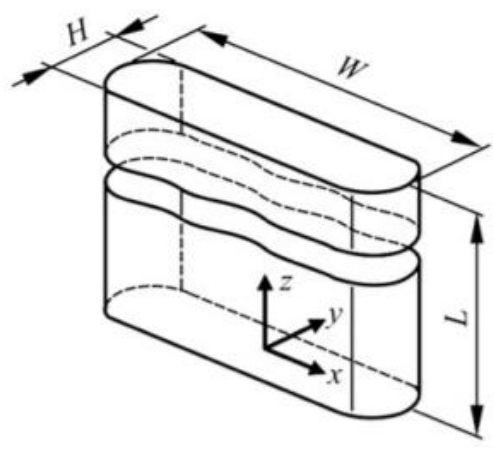

Figure 1. Physical model of flattened tube

\subsection{Governing equations}

The single phase model to investigate the thermal and fluid dynamic behavior of hybrid nanofluids was employed. The governing equations adopted in this study were based on the following assumptions: steady state process, fluid inside the flattened tube was Newtonian and incompressible, and radiative effect was negligible. Also, governing equations were solved in the Cartesian coordinate system using the ANSYS CFX-14.0 software.

The continuity equation:

$\frac{\partial}{\partial x_{i}}\left(\rho U_{i}\right)=0$

The momentum equations:

$\frac{\partial}{\partial x_{i}}\left(\rho U_{j} U_{i}\right)=-\frac{\partial P}{\partial x_{j}}+\frac{\partial}{\partial x_{i}}\left(\mu\left(\frac{\partial U_{j}}{\partial x_{i}}\right)\right)$ where $i, j \in\{1,2,3\}$.

The energy equation was solved to calculate the temperature distribution:

$$
\frac{\partial}{\partial x_{i}}\left(\rho c_{p} U_{j} T\right)=\frac{\partial}{\partial x_{i}}\left(k\left(\frac{\partial T_{i}}{\partial x_{i}}\right)\right)
$$

\subsection{Grid independence test and validation}

In order to grid independence test, three grid sizes were compared in terms of velocity and temperature. A multi-block meshing scheme with hexahedral elements was used for the generation of the structure grids (Fig.2).

Figure 2. Grid layout used in the present analysis

Table 1 summarizes the grid independence study by comparing the velocity and temperatures profiles for water at $\mathrm{Re}=100, \mathrm{~T}=313.15 \mathrm{~K}$ and $\mathrm{Y}=0 \mathrm{~m}$. After this grid independence study, grid II $90 \times 40 \times 200$ was chosen as the optimal grid size.

Table 1. Grid independence study

\begin{tabular}{|c|c|c|}
\hline Grid & Velocity $[\mathrm{m} / \mathrm{s}]$ & Temperature $[\mathrm{K}]$ \\
\hline $60 \times 20 \times 100$ & 0.02420 & 309.013 \\
\hline $90 \times 40 \times 200$ & 0.02421 & 309.016 \\
\hline $120 \times 60 \times 300$ & 0.02422 & 309.016 \\
\hline
\end{tabular}

In order to validation of the numerical model, the results were compared with the Shah and London correlation [10] and also with the numerical results carried out by Vajjha [6].

Shah and London correlations [10] for the constant wall heat flux in a circular tube under laminar flow are given below:

$$
\begin{aligned}
& N u=1.953\left(\operatorname{Re} \operatorname{Pr} \frac{d_{h}}{L}\right)^{1 / 3} \\
& \operatorname{for}\left(\operatorname{Re} \operatorname{Pr} \frac{d_{h}}{L}\right) \geq 33.33 \\
& N u=4.364+0.0722\left(\operatorname{Re} \operatorname{Pr} \frac{d_{h}}{L}\right) \\
& \text { for }\left(\operatorname{Re} \operatorname{Pr} \frac{d_{h}}{L}\right)<33.33
\end{aligned}
$$

In Eqs. (4) and (5), the hydraulic diameter of the flattened tube was $d_{h}=4.536 \cdot 10^{-3} \mathrm{~m}$. The Reynolds and Prandtl numbers were defined as:

$$
\operatorname{Re}=\frac{U d_{h}}{v}=\frac{\rho U d_{h}}{\mu} \text { and } \operatorname{Pr}=\frac{\mu c_{p}}{k}
$$

As seen in Table 2 there a good agreement between the 
calculated results and reported theoretical and numerical results.

Table 2. The validation of numerical model

\begin{tabular}{|c|c|c|}
\hline Working fluid & \multicolumn{2}{|c|}{ Nusselt number, $\mathrm{Nu}$} \\
\hline \multirow{5}{*}{ Water } & $\begin{array}{c}\text { Shah-London } \\
\text { correlation [10] }\end{array}$ & Numerical results \\
\hline & \multicolumn{2}{|c|}{$\operatorname{Re}=75$} \\
\hline & 4.575 & 4.695 \\
\hline & \multicolumn{2}{|c|}{$R e=100$} \\
\hline & 4.646 & 5.566 \\
\hline \multirow{3}{*}{$\begin{array}{l}\text { Ethylene } \\
\text { glycol }\end{array}$} & Vajjha et al.[6] & Numerical results \\
\hline & \multicolumn{2}{|c|}{$R e=100$} \\
\hline & 6.49 & 6.68 \\
\hline
\end{tabular}

\subsection{Boundary conditions}

Numerical simulations were performed in a laminar flow with the Reynolds numbers in the range of 50-1000 for hybrid nanofluids based on water with volume concentrations of $0.1 \%$ and $0.3 \%$ for $\mathrm{MWNCT}+\mathrm{Fe}_{3} \mathrm{O}_{4}$ hybrid nanoparticles.

In this study, the boundary conditions imposed were the following:

- Inlet: velocity $(\mathrm{Re}=50-1000)$ and temperature $(\mathrm{T}=313$ $\mathrm{K}$ );

- $\quad$ Outlet: pressure $(\mathrm{P}=0)$;

- Wall: heat transfer coefficient $\left(\mathrm{h}=50 \mathrm{~W} / \mathrm{m}^{2} \mathrm{~K}\right)$ and temperature $(\mathrm{T}=293 \mathrm{~K})$, non-slip condition;

- Interference surfaces of the domains: conservative interface flux.

\subsection{Data reduction}

Heat transfer rate can be expressed as

$Q=\dot{m} c_{p}\left(T_{\text {in }}-T_{\text {out }}\right)$

Heat transfer coefficient can be written

$h=\frac{Q}{A_{p}\left(T_{b}-T_{w}\right)}=\frac{\dot{m} c_{p}\left(T_{\text {in }}-T_{\text {out }}\right)}{A_{p}\left(T_{b}-T_{w}\right)}$

Peripheral area is

$A_{p}=2(L H+L W)$

Hydraulic diameter of tubes is given by

$d_{h}=4 \frac{A}{P}$

\section{THERMO-PHYSICAL PROPERTIES OF HYBRID NANOFLUIDS}

The thermo-physical properties of hybrid nanofluids used in this study were chosen from the study of Sundar et al. [11]. In Table 3 were presented the thermo-physical properties of water based on $\mathrm{MWCNT}-\mathrm{Fe}_{3} \mathrm{O}_{4} \quad(26 \%: 74 \%)$ hybrid nanoparticles.
Table 3. Thermo-physical properties of water [12] and $\mathrm{MWCNT}+\mathrm{Fe}_{3} \mathrm{O}_{4} /$ water at $313 \mathrm{~K}$ [11]

\begin{tabular}{|c|c|c|c|}
\hline Working fluid & \multirow[b]{2}{*}{ Water } & \multicolumn{2}{|c|}{${\mathrm{MWCNT}-\mathrm{Fe}_{3} \mathrm{O}_{4} / \text { water }}$} \\
\hline $\begin{array}{l}\text { Thermo- } \\
\text { physical } \\
\text { properties }\end{array}$ & & $\phi=0.1 \%$ & $\phi=0.3 \%$ \\
\hline $\begin{array}{l}\text { Thermal } \\
\text { conductivity } \\
{[\mathrm{W} / \mathrm{mK}]}\end{array}$ & 0.633 & 0.720 & 0.7656 \\
\hline $\begin{array}{l}\text { Viscosity } \\
{[\mathrm{Pa} \mathrm{s}]}\end{array}$ & $0.658 \cdot 10^{-3}$ & $0.610 \cdot 10^{-3}$ & $0.760 \cdot 10^{-3}$ \\
\hline $\begin{array}{l}\text { Density } \\
{\left[\mathrm{kg} / \mathrm{m}^{3}\right]}\end{array}$ & 992.20 & 995.85 & 1003.56 \\
\hline $\begin{array}{l}\text { Specific heat } \\
{[\mathrm{J} / \mathrm{kg} \mathrm{K}]}\end{array}$ & 4175 & 4179.66 & 4180.99 \\
\hline
\end{tabular}

\section{RESULTS AND DISCUSSIONS}

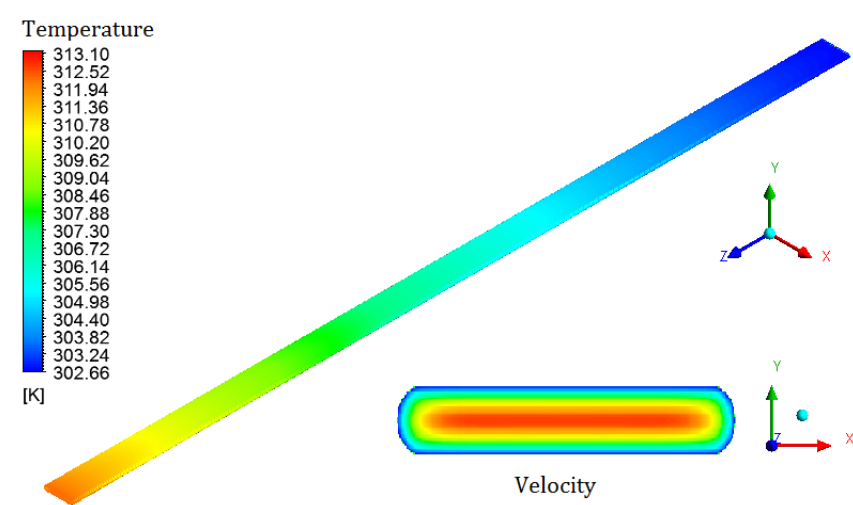

Figure 3 Temperature distribution and velocity profile for water at $\mathrm{Re}=50$

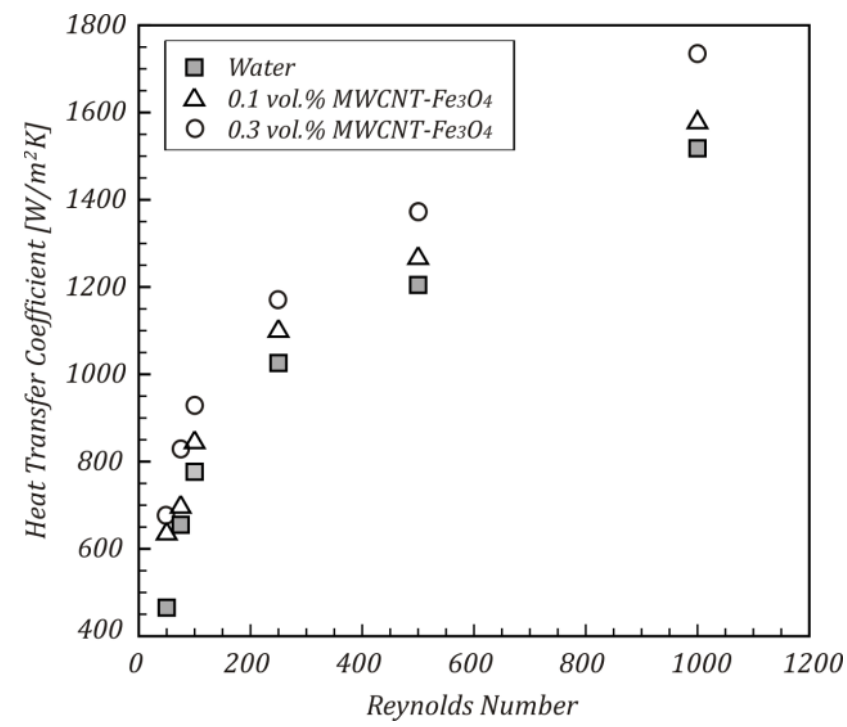

Figure 4. The variation of the heat transfer coefficient for different Reynolds number

In the present study, the heat transfer performances of flattened tube using hybrids nanofluid with volume concentrations of $0.1 \%$ and $0.3 \%$ of MWCNT-Fe ${ }_{3} \mathrm{O}_{4}$ hybrid nanoparticles in water were studied at different Reynolds numbers $(\mathrm{Re}=50-1000)$ and at the temperature of $\mathrm{T}=313.15 \mathrm{~K}$.

The temperature and velocity profiles for water of the flattened tube at $\mathrm{Re}=50$ were given in Fig. 3 . 
Fig. 4 shows the results of the average heat transfer coefficient for the Reynolds number within the range $\mathrm{Re}=50$ 1000, and two concentrations of $\mathrm{MWCNT}-\mathrm{Fe}_{3} \mathrm{O}_{4}$ hybrid nanoparticles. As shown, heat transfer coefficient increases with increasing Reynolds number and increasing concentration of nanoparticles. Also, at low Reynolds numbers, the heat transfer coefficient increase was significantly higher than at high Reynolds numbers. Moreover, it is observed that heat transfer coefficient of hybrid nanofluids was considerably higher than that of water (base fluid).

Fig. 5 shows the effect of the Reynolds number on the ratio of convective heat transfer coefficient $\left(h_{n f} / h_{b f}\right)$ defined as the ratio between the heat transfer coefficient of hybrid nanofluid $\left(h_{n f}\right)$ and the heat transfer coefficient of base fluid $\left(h_{b f}\right)$. From the numerical results, higher heat transfer coefficient ratio can be observed with increasing of the concentration of hybrid nanoparticles in water. The maximum heat transfer coefficient ratio was 1.45 at 0.3 vol.\% $\mathrm{MWCNT}-\mathrm{Fe}_{3} \mathrm{O}_{4}$ hybrid nanoparticles and $\mathrm{Re}=50$. At same concentration of hybrid nanoparticles and $\mathrm{Re}=1000$, heat transfer coefficient ratio was 1.143. Also, heat transfer coefficient ratio decreases with increasing Reynolds number for all studied concentrations of nanoparticles.

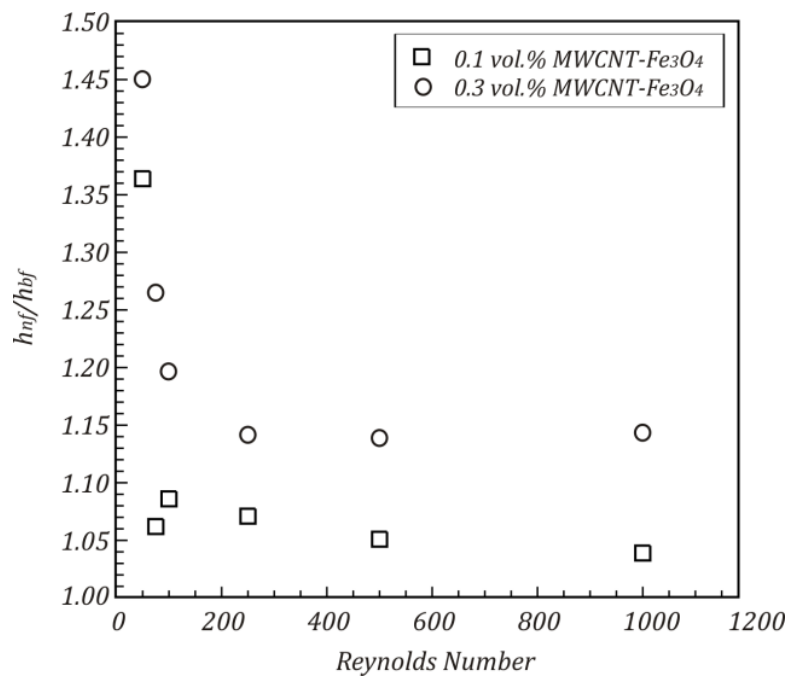

Figure 5. The heat transfer coefficient ratio versus Reynolds number

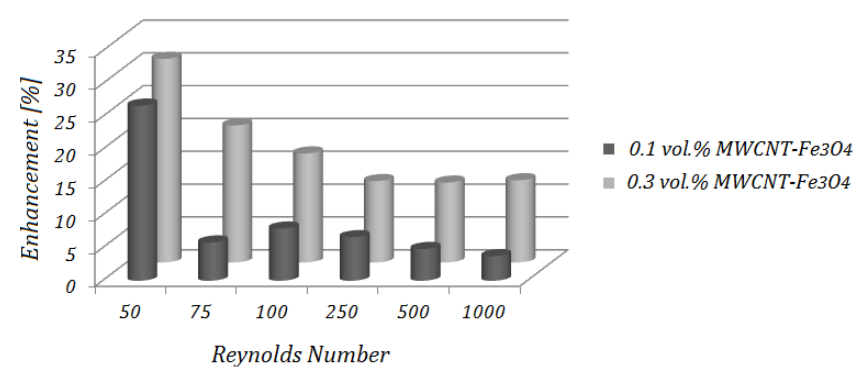

Figure 6. The heat transfer enhancement for different Reynolds number

The heat transfer enhancement for different Reynolds number and concentrations of hybrid nanoparticles is shown in Fig. 6. As shown in Fig. 6, the heat transfer enhancement increases with increasing concentration of hybrid nanoparticles and decreases with increasing Reynolds number.

The maximum enhancement $\left(100\left(\mathrm{~h}_{\mathrm{nf}}-\mathrm{h}_{\mathrm{bf}}\right) / \mathrm{h}_{\mathrm{bf}}\right)$ was $31 \%$ for a concentration of 0.3 vol.\% nanoparticles and a Reynolds number of $\mathrm{Re}=50$. At same Reynolds number, the enhancement of heat transfer coefficient for a concentration of the nanoparticles of $0.1 \%$ was $26.68 \%$.

The pumping power required to circulate the working fluid can be expressed as:

$W=A U(\Delta P)$

The table 4 shows the pressure loss and the pumping power at different Reynolds numbers. As seen, the pressure loss increases with increasing Reynolds number in all cases. When using $0.1 \%$ MWCNT- $-\mathrm{Fe}_{3} \mathrm{O}_{4}$ hybrid nanoparticles in flattened tube, the pressure loss increases up $\mathrm{Re}=250$, after which it can be observed a decrease of it compared with the water (base fluid). Also, at a concentration of $0.3 \%$ MWCNT- $-\mathrm{Fe}_{3} \mathrm{O}_{4}$ hybrid nanoparticles, the pressure loss increases compared with water and $0.1 \%$ MWCNT- $\mathrm{Fe}_{3} \mathrm{O}_{4}$ hybrid nanofluid. Furthermore, it can be seen a decrease of the pumping power at a concentration of $0.1 \%$ nanoparticles and Reynolds numbers in the range 75-1000 compared cu water, while at a concentration of $0.3 \%$ can be observed a significantly increase of the pumping power.

Table 4. Pressure loss and the pumping power in a flattened tube using hybrid nanofluids

\begin{tabular}{|c|c|c|c|c|c|c|}
\hline $\begin{array}{l}\text { Reynolds } \\
\text { number }\end{array}$ & 50 & 75 & 100 & 250 & 500 & 1000 \\
\hline \multicolumn{7}{|c|}{ Water } \\
\hline $\begin{array}{l}\text { Pressure } \\
\text { loss }[\mathrm{Pa}]\end{array}$ & 18.21 & 23.69 & 28.55 & 50.07 & 85.52 & $\begin{array}{l}157.9 \\
2\end{array}$ \\
\hline Power [W] & $\begin{array}{l}5.28 \\
10^{-6} \\
\end{array}$ & $\begin{array}{l}1.04 \\
10^{-5} \\
\end{array}$ & $\begin{array}{l}1.71 \cdot \\
10^{-5} \\
\end{array}$ & $\begin{array}{l}7.20 \\
10^{-5} \\
\end{array}$ & $\begin{array}{l}2.48 \\
10^{-4}\end{array}$ & $\begin{array}{l}9.15 \\
10^{-4} \\
\end{array}$ \\
\hline \multicolumn{7}{|c|}{$0.1 \% \mathrm{MWCNT}-\mathrm{Fe}_{3} \mathrm{O}_{4}$} \\
\hline $\begin{array}{l}\text { Pressure } \\
\text { loss }[\mathrm{Pa}]\end{array}$ & 20.33 & 25.02 & 29.87 & 50.57 & 84.09 & $\begin{array}{l}151.9 \\
9\end{array}$ \\
\hline Power [W] & $\begin{array}{l}5.48 \\
10^{-6} \\
\end{array}$ & $\begin{array}{l}1.0 \\
10^{-5} \\
\end{array}$ & $\begin{array}{l}1.67 \\
10^{-5} \\
\end{array}$ & $\begin{array}{l}6.87 \\
10^{-5} \\
\end{array}$ & $\begin{array}{l}2.28 \\
10^{-4} \\
\end{array}$ & $\begin{array}{l}8.20 \\
10^{-4} \\
\end{array}$ \\
\hline $\begin{array}{l}\% \text { Power } \\
\text { reduction }\end{array}$ & 3.92 & -3.97 & -2.35 & -4.62 & -7.81 & -10.4 \\
\hline \multicolumn{7}{|c|}{$0.3 \% \mathrm{MWCNT}-\mathrm{Fe}_{3} \mathrm{O}_{4}$} \\
\hline $\begin{array}{l}\text { Pressure } \\
\text { loss }[\mathrm{Pa}]\end{array}$ & 27.67 & 34.51 & 39.61 & 67.81 & $\begin{array}{l}122.6 \\
7\end{array}$ & $\begin{array}{l}207.9 \\
8\end{array}$ \\
\hline Power [W] & $\begin{array}{l}9.23 \\
10^{-6} \\
\end{array}$ & $\begin{array}{l}1.79 \\
10^{-5} \\
\end{array}$ & $\begin{array}{l}2.69 \\
10^{-5} \\
\end{array}$ & $\begin{array}{l}1.14 \\
10^{-4} \\
\end{array}$ & $\begin{array}{l}4.07 \\
10^{-4} \\
\end{array}$ & $\begin{array}{l}1.39 \\
10^{-3} \\
\end{array}$ \\
\hline $\begin{array}{l}\% \text { Power } \\
\text { reduction }\end{array}$ & 74.85 & 72.18 & 57.21 & 58.01 & 64.16 & 51.68 \\
\hline
\end{tabular}

\section{CONCLUSIONS}

The heat transfer performances of a flattened tube were numerically investigated using water based MWCNT- $\mathrm{Fe}_{3} \mathrm{O}_{4}$ hybrid nanofluids in laminar flow. The influence of the Reynolds number and volume concentration of hybrid nanoparticles on the cooling performances of hybrid nanofluids and water were studied. The numerically results showed that the heat transfer coefficients of the MWCNT$\mathrm{Fe}_{3} \mathrm{O}_{4} /$ water hybrid nanofluids were significantly higher than those of the base fluid (water). The increase in heat transfer coefficients was higher at low Reynolds numbers. The heat transfer enhancement of hybrid nanofluids depends of the volume concentration of hybrid nanoparticles, increasing 
concentration of hybrid nanoparticles of $0.3 \%$ showing a maximum heat transfer enhancement of $31 \%$.

\section{REFERENCES}

[1] Huminic G., Huminic A., Fleaca C., Dumitrache F. (2016). Heat transfer characteristics of a two-phase closed thermosyphons using nanofluids based on $\mathrm{SiC}$ nanoparticles, International Journal of Heat and Technology, Vol. 34, Sp. 2, pp. S199-S204. DOI: https://doi.org/10.18280/ijht.34S202

[2] Wang X.H., Jiao Y.L., Niu Y.C., Yang J. (2015). Study on enhanced heat transfer features of nano-magnetic fluid heat pipe under magnetic field, International Journal of Heat and Technology, Vol. 33, pp. 137-143. DOI: $10.18280 /$ ijht.330119

[3] Sivakumar A., Alagumurthi N., Senthilvelan T. (2015). Experimental and numerical investigation of forced convective heat transfer coefficient in nanofluids of $\mathrm{Al}_{2} \mathrm{O}_{3} /$ water and $\mathrm{CuO} / \mathrm{EG}$ in a serpentine shaped microchannel heat sink, International Journal of Heat and Technology, Vol. 33, pp. 155-160. DOI: $\underline{10.18280 / i j h t .330121}$

[4] Bigdeli M.B., Fasano M., Cardellini A., Chiavazzo E., Asinari P. (2016). A review on the heat and mass transfer phenomena in nanofluid coolants with special focus on automotive applications, Renewable and Sustainable Energy Reviews, Vol. 60, pp.1615-1633. DOI: $10.1016 /$ j.rser.2016.03.027

[5] Zhao N., Li S., Yang J. (2016). A review on nanofluids: Datadriven modeling of thermalphysical properties and the application in automotive radiator, Renewable and Sustainable Energy Reviews, Vol. 66, pp. 596-616. DOI: 10.1016/i.rser.2016.08.029

[6] Vajjha R.S., Das D.K., Namburu P.K. (2010). Numerical study of fluid dynamic and heat transfer performance of $\mathrm{Al}_{2} \mathrm{O}_{3}$ and $\mathrm{CuO}$ nanofluids in the flat tubes of a radiator, International Journal of Heat and Fluid Flow, Vol. 31 pp. 613-621. DOI: 10.1016/j.ijheatfluidflow.2010.02.016

[7] Huminic G., Huminic A. (2013). Numerical analysis of laminar flow heat transfer of nanofluids in a flattened tube, International Communications in Heat and Mass Transfer, Vol. 44, pp. 52-57. DOI: 10.1016/j.icheatmasstransfer.2013.03.003

[8] Delavari V., Hashemabadi S.H. (2014). CFD simulation of heat transfer enhancement of $\mathrm{Al}_{2} \mathrm{O}_{3} /$ water and $\mathrm{Al}_{2} \mathrm{O}_{3}$ /ethylene glycol nanofluids in a car radiator, Applied Thermal Engineering, Vol. 73, pp. 380-390. DOI: $10.1016 /$ i.applthermaleng.2014.07.061

[9] Elsebay M., Elbadawy I., Shedid M.H., Fatouh M. (2016). Numerical resizing study of $\mathrm{Al}_{2} \mathrm{O}_{3}$ and $\mathrm{CuO}$

nanofluids in the flat tubes of a radiator, Applied Mathematical Modelling, Vol. 40, pp. 6437-6450. DOI: 10.1016/j.apm.2016.01.039

[10] Shah R.K., London A.L. (1978). Laminar flow forced convection in ducts, Journal of Fluids Engineering, Vol. 102, No. 2, pp. 431-455.

[11] Sundar L.S., Singh M.K., Sousa A.C.M. (2014). Enhanced heat transfer and friction factor of MWCNT$\mathrm{Fe}_{3} \mathrm{O}_{4} /$ water hybrid nanofluids, International Communications in Heat and Mass Transfer, Vol. 52, pp. 73-83.

DOI: 10.1016/i.icheatmasstransfer.2014.01.012

[12] Raznjevic K. (1975). Thermodynamic Diagrams and Tables, Bucharest, Romania: Technical Press, pp. 112

\section{NOMENCLATURE}

A

$A_{p}$

$c_{p}$

dh

$\mathrm{h}$

$\mathrm{H}$

$\mathrm{k}$

$\mathrm{L}$

$\dot{m}$

$\mathrm{Nu}$

$\mathrm{P}$

$P$

$\operatorname{Pr}$

Q

$\operatorname{Re}$

$\mathrm{T}$

U

W

W

$\mathrm{x}$

\section{Greek symbols}

$\rho$

$v$

$\mu$

\section{Subscripts}

b

in

out

W tube surface area, $\mathrm{m}^{2}$

peripheral area, $\mathrm{m}^{2}$

specific heat, $\mathrm{J} \mathrm{Kg}^{-1} \cdot \mathrm{K}^{-1}$

hydraulic diameter of the tube, $\mathrm{m}$

heat transfer coefficient, $\mathrm{W} \cdot \mathrm{m}^{-2} \cdot \mathrm{K}^{-1}$

height, $\mathrm{m}$

thermal conductivity, $\mathrm{W} \cdot \mathrm{m}^{-1} \cdot \mathrm{K}^{-1}$

length, $\mathrm{m}$

mass flow rate, kg. $\mathrm{s}^{-1}$

Nusselt number

pressure, $\mathrm{Pa}$

perimeter, $\mathrm{m}$

Prandtl number

heat transfer rate, $\mathrm{W}$

Reynolds number

temperature, $\mathrm{K}$

velocity, $\mathrm{m} \cdot \mathrm{s}^{-1}$

width, $\mathrm{m}$

power, W (Eq. 10)

cartesian coordinates, $\mathrm{m}$

density, kg. $\mathrm{m}^{-3}$

kinematic viscosity, $\mathrm{m} 2 . \mathrm{s}^{-1}$

dinamic viscosity, Pa s bulk

inlet

outlet

wall 